\title{
Estimation of monthly stream flows based on the sequential water budget technique applied to the Thornthwaite potential evapotranspiration
}

\author{
M. M. Portela ${ }^{1}$ \& J. F. Santos ${ }^{2}$ \\ ${ }^{I}$ Department of Civil Engineering and Architecture, Environment and \\ Water Resources Division, IST, Technical University of Lisbon, Portugal \\ ${ }^{2}$ Department of Engineering, ESTIG, Beja, Portugal
}

\begin{abstract}
In mainland Portugal, the measurement of stream flows started later than the measurement of the majority of the other hydrologic variables. Also the former measurements were not carried out systematically, thus resulting in stream flow series not only with several faults, but also with reduced length, circumstances that often compromise their utilization either for research or design purposes. Based on the records at sixteen Portuguese climatologic stations it is stressed that the sequential water budget technique applied to the Thornthwaite potential evapotranspiration may provide a monthly stream flow evaluation model having in view the fulfilment but, especially, the extension of monthly flow data. As the number of parameters and the data requirements of the previous technique and model are relatively modest it is possible, by that way, to estimate monthly stream flows even in regions with scarce hydrologic information.

Keywords: sequential water budge, Thornthwaite and Penman-Monteith potential evapotranspirations, evaluation of monthly stream flows.
\end{abstract}

\section{Introduction: scope of the study}

In Portugal mainland, the extensive and systematic measurement of stream flows started later than that of the majority of the other hydrologic variables. Furthermore, the corresponding series of flow records present not only frequent sporadic flaws but also long interruptions thereby limiting their use for both 
scientific hydrologic studies and design of hydraulic infrastructures. This brings forward the need to establish models of estimating the flows that allow for the filling in of the gaps in the records and, more importantly, to increase the span of such records. The efficiency of such models depends, however, on their capability to produce flow estimates based on variables for which measurements are expected to be readily available such as rainfall and, to a certain extent, temperature. The sequential water budget technique and the more recent Temez model stand out among the available models. However, both of them make use of the potential evapotranspiration accurate evaluation of which requires records of climatologic variables that are not usually easily available except for rainfall and temperature.

In this context, the present study aims at comparing the estimates of monthly stream flows obtained via the sequential water budget technique applied under consideration of two different methods of evaluation of the potential evapotranspiration: the Thornthwaite method and the Penman-Monteith method. The former is recognizably simple since it only makes use of average monthly temperatures. Conversely the latter, requiring records of several climatologic variables, becomes, in practice, much more restricted.

\section{The potential evapotranspiration: the sequential water budget technique}

Potential evapotranspiration (EVP) is defined as the process of transfer of water from the soil to the atmosphere, either directly or through the plants, assuming that the water required for the process is fully available.

According to Thornthwaite [8], the EVP (mm/month) for one month with $\mathrm{N}_{\mathrm{d}}$ days is given by the following equation:

$$
E V P=\left[16 \times\left(10 \frac{\text { Tmed }}{I}\right)^{\alpha}\right] \times\left[\frac{N / 12 \times N_{d}}{30}\right]
$$

where Tmed is the average air temperature $\left({ }^{\circ} \mathrm{C}\right)$ in that month; I is an annual heat index which depends on the monthly heat indexes which, in turn, are function of the average air temperatures along the several months of the year; $\alpha$ is an exponent which also depends on I; and N/12 is the astronomic duration of the day in $12 \mathrm{~h}$ units of a 30 day month, defined as a function of the latitude of the place where EVP is to be calculated.

The Penman-Monteith method yields the to the potential evapotranspiration for a soil completely covered by a reference culture (grass in active growth, with uniform height and free of water supply limitations, Pereira et al. [5]) and, for this reason, this evapotranspiration is frequently called reference evapotranspiration, EV0. The calculation of EV0 ( $\mathrm{mm} /$ day) for a given place can be done by means of the following equation, Pereira et al. [5]:

$$
E V 0=\frac{0.408 \Delta\left(R_{n}-g\right)+\gamma \frac{900}{\text { Tmed }+273} v_{2}\left(e_{a}-e_{d}\right)}{\Delta+\gamma\left(1+0.34 U_{2}\right)}
$$


where Tmed is the average air temperature $\left({ }^{\circ} \mathrm{C}\right) ; \Delta$ the slope of the curve of the vapour tension in the atmosphere $\left(\mathrm{k} \mathrm{Pa}{ }^{\circ} \mathrm{C}^{-1}\right) ; \mathrm{R}_{\mathrm{n}}$ the net solar radiation $\left(\mathrm{MJ} \mathrm{m}^{-2} \mathrm{~d}^{-1}\right)$; $\mathrm{g}$ the heat flux of the soil $\left(\mathrm{MJ} \mathrm{m}^{-2} \mathrm{~d}^{-1}\right) ; \gamma$ a constant $\left(\mathrm{k} \mathrm{Pa}^{\circ} \mathrm{C}^{-1}\right)$; $\mathrm{v}_{2}$ the mean wind velocity $2 \mathrm{~m}$ above the ground $\left(\mathrm{ms}^{-1}\right) ; \mathrm{e}_{\mathrm{a}}$ the vapour saturation tension at temperature $\mathrm{T}(\mathrm{kPa})$; and $\mathrm{e}_{\mathrm{d}}$ is the actual vapour tension $(\mathrm{kPa})$. The calculation of some of the previous variables, besides its complexity, may also require the average maximum and average minimum air temperatures, the average air relative humidity and the global solar radiation.

The method of Thornthwaite seems to underestimate the potential evapotranspiration in Portugal mainland (Quintela [7] and Lencastre and Franco [2]) while the method of Penman-Monteith has a tendency to overestimate it, Pereira et al. [5], its results being, however, more satisfactory in a large number of different climatic, time scale and location constraints.

The sequential water budget technique (Thornthwaite [8], Carter [1], Mather [3, 4], Varennes and Mendonça [9], Lencastre and Franco [2]) uses the mass equation applied to an element of the terrestrial phase of the hydrologic cycle by way of calculating the water fluxes "entering" that element, those "leaving" it and the variations in the water storage within that same element, according to:

$$
P=S+E V A+\Delta S
$$

where, for a given time interval, $\mathrm{P}$ is the rainfall; $\mathrm{S}$ the water excess or superavit; EVA the actual evapotranspiration; and $\Delta \mathrm{S}$ the water storage variation (all variables expressed in the same units).

The water budget technique does not take into account the heterogeneity of the watershed, the deep infiltration and the complexity of the water movements (either on the surface or in the ground). Also, it does not consider that surface runoff occurs whenever the rainfall intensity exceeds the infiltration rate. Despite these simplifications, it may be considered that the water excess or superavit, $\mathrm{S}$, represents the upper limit of the surface flow.

Within these provisos, the sequential water budget technique may be applied to estimate the surface flows. In order to do so and after assigning to the soil a maximum useable water capacity, Smax, the technique assumes that, as long as there is water availability (either in the ground or from the rainfall), the actual evapotranspiration rate equals that of the potential evapotranspiration; otherwise, it will occur at a lower rate. Furthermore, it also assumes that there is no onset of surface flow as long as the capacity to store water in the soil is not filled up, even if the rainfall intensity exceeds the infiltration rate. The amount of water in the soil in the months where rainfall is lower than evapotranspiration can be calculated according to, Varennes and Mendonça [9]:

$$
A S_{i}=S \max \cdot e^{L_{i} / S \max }
$$

where, besides Smax, $\mathrm{AS}_{\mathrm{i}}(\mathrm{mm})$ represents the water in the soil in month $\mathrm{i}$ and $\mathrm{L}_{\mathrm{i}}(\mathrm{mm})$ the water potential loss (that is, the difference between the rainfall and the potential evapotranspiration) accumulated since the onset of the dry period up to month i. 


\section{Data and results}

Based on the monthly records of rainfall $(\mathrm{P})$, air temperature - mean (Tmed), average maximum (Tmax) and average minimum (Tmin) -, air relative humidity (HR), sunny hours (I), and wind velocity (v) in the sixteen climatologic stations identified in Table 1 and located in Figure 1, the potential evapotranspiration of Thornthwaite and of Penman-Monteith were computed, as well as the surface flows that they predict based on the sequential water budget technique.

Table 1: Climatologic stations. General features and mean monthly values ${ }^{1}$ of P, Tmed, Tmax, Tmin, HR, I and v.

\begin{tabular}{|c|c|c|c|c|c|c|c|c|c|c|c|}
\hline \multirow{2}{*}{ Climatologic station } & \multirow{2}{*}{ Period with records } & \multicolumn{2}{|c|}{ Location } & \multirow{2}{*}{$\begin{array}{c}\text { Altitude } \\
\text { (m) }\end{array}$} & \multicolumn{7}{|c|}{ Mean monthly values } \\
\hline & & Lat & Long & & $\begin{array}{c}\mathrm{P} \\
(\mathrm{mm})\end{array}$ & $\begin{array}{c}\text { Tmed } \\
\left({ }^{\circ}\right)\end{array}$ & $\begin{array}{c}T \max \\
\left({ }^{\circ}\right)\end{array}$ & $\begin{array}{c}\text { Tmin } \\
\left({ }^{\circ}\right)\end{array}$ & $\begin{array}{l}\text { HR } \\
(\%) \\
\end{array}$ & $\begin{array}{c}\mathrm{I} \\
(\mathrm{h})\end{array}$ & $\begin{array}{c}\mathrm{v} \\
(\mathrm{m} / \mathrm{s})\end{array}$ \\
\hline Bragança $(03 \mathrm{Q} / 01)$ & $1963 / 64-1987 / 88$ & $41^{\circ} 48^{\prime}$ & $6^{\circ} 44^{\prime}$ & 690 & 61.86 & 12.06 & 17.37 & 6.62 & 79.69 & 213.7 & 10.05 \\
\hline Mirandela (04N/02) & $1959 / 60-1980 / 81$ & $41^{\circ} 31^{\prime}$ & $7^{\circ} 12^{\prime}$ & 250 & 44.33 & 14.12 & 20.36 & 7.91 & 72.66 & 210.1 & 7.14 \\
\hline Miranda do Douro (05T/01) & $1956 / 57-1965 / 66$ & $41^{\circ} 30^{\prime}$ & $6^{\circ} 17^{\prime}$ & 693 & 45.94 & 12.36 & 17.68 & 7.15 & 72.23 & 219.8 & 13.86 \\
\hline Vila Real $(06 \mathrm{~K} / 01)$ & $1959 / 60-1987 / 88$ & $41^{\circ} 19^{\prime}$ & $7^{\circ} 44^{\prime}$ & 481 & 99.27 & 13.30 & 18.55 & 8.10 & 82.86 & 195.9 & 7.05 \\
\hline Régua (07K/01) & $1959 / 60-1987 / 88$ & $41^{\circ} 10^{\prime}$ & $7^{\circ} 48^{\prime}$ & 65 & 78.95 & 15.43 & 21.69 & 9.20 & 77.52 & 186.9 & 5.18 \\
\hline Viseu $(10 \mathrm{~J} / 01)$ & $1961 / 62-1975 / 76$ & $40^{\circ} 40^{\prime}$ & $7^{\circ} 54^{\prime}$ & 443 & 97.64 & 13.04 & 19.12 & 7.06 & 78.32 & 215.6 & 4.87 \\
\hline Coimbra - Bencanta $(12 \mathrm{G} / 06)$ & $1959 / 60-1987 / 88$ & $40^{\circ} 13^{\prime}$ & $8^{\circ} 27^{\prime}$ & 27 & 86.15 & 15.26 & 20.72 & 9.72 & 79.94 & 192.8 & 4.93 \\
\hline Fundão $(13 \mathrm{~L} / 01)$ & $1957 / 58-1963 / 64$ & $40^{\circ} 08^{\prime}$ & $7^{\circ} 30^{\prime}$ & 495 & 93.81 & 14.19 & 19.65 & 8.75 & 65.90 & 231.6 & 8.80 \\
\hline Alcobaça/E. Fruticultura (16D/06) & $1960 / 61-1976 / 77$ & $39^{\circ} 031^{\prime}$ & $8^{\circ} 58^{\prime}$ & 38 & 80.64 & 14.91 & 19.72 & 9.37 & 81.86 & 205.8 & 8.17 \\
\hline Portalegre $(18 \mathrm{M} / 01)$ & $1959 / 60-1987 / 88$ & $39^{\circ} 17^{\prime}$ & $7^{\circ} 25^{\prime}$ & 597 & 75.75 & 15.03 & 19.49 & 10.54 & 72.53 & 223.6 & 14.06 \\
\hline Ota (Base Aérea) $(19 \mathrm{D} / 01)$ & $1976 / 77-1983 / 84$ & $39^{\circ} 07^{\prime}$ & $8^{\circ} 59^{\prime}$ & 40 & 56.49 & 16.22 & 21.26 & 11.18 & 78.29 & 216.7 & 10.61 \\
\hline Sassoeiros (21B/03) & $1958 / 59-1967 / 68$ & $38^{\circ} 42^{\prime}$ & $9^{\circ} 19^{\prime}$ & 50 & 59.29 & 15.95 & 20.17 & 11.68 & 77.14 & 214.4 & 13.55 \\
\hline Lisboa (IGIDL) (21C/06) & $1958 / 59-1987 / 88$ & $38^{\circ} 43^{\prime}$ & $9^{\circ} 09^{\prime}$ & 77 & 63.74 & 16.72 & 20.77 & 12.73 & 75.40 & 233.8 & 13.53 \\
\hline Évora - Cemitério (22J/02) & $1956 / 57-1987 / 88$ & $38^{\circ} 34^{\prime}$ & $7^{\circ} 55^{\prime}$ & 265 & 54.38 & 15.66 & 20.43 & 10.83 & 80.70 & 232.9 & 15.81 \\
\hline Viana do Alentejo (23I/02) & $1958 / 59-1984 / 85$ & $38^{\circ} 20^{\prime}$ & $8^{\circ} 03^{\prime}$ & 202 & 55.04 & 16.00 & 22.36 & 9.63 & 76.39 & 232.6 & 8.76 \\
\hline Beja $(25 \mathrm{~J} / 02)$ & $1958 / 59-1987 / 88$ & $38^{\circ} 01^{\prime}$ & $7^{\circ} 52^{\prime}$ & 246 & 49.22 & 16.09 & 22.16 & 10.05 & 85.00 & 229.0 & 15.23 \\
\hline
\end{tabular}

${ }^{1}$ Referred to the hydrological year, starting October $1^{\text {st }}$.

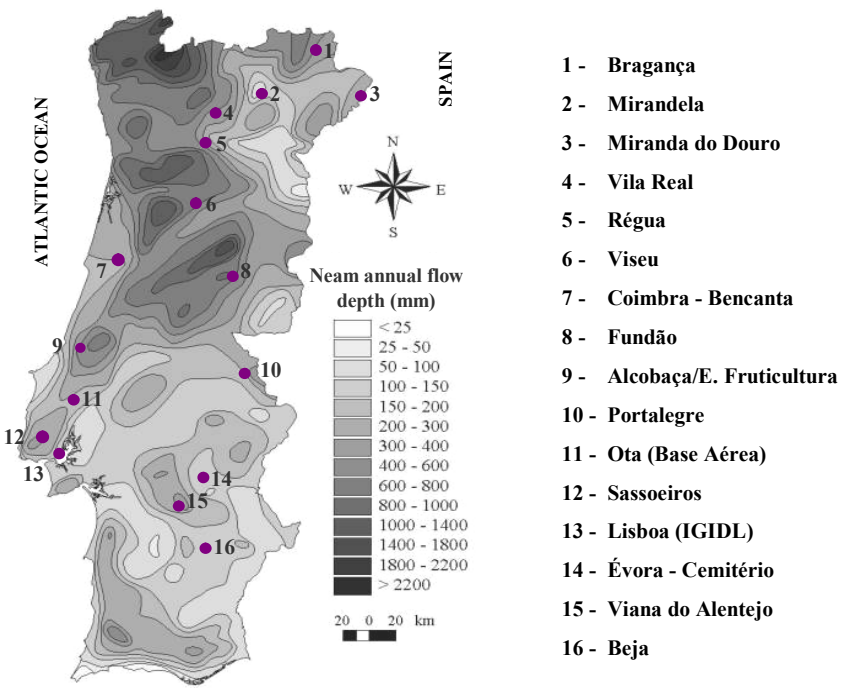

Figure 1: $\quad$ Location of the climatologic stations of Table 1. 
In Figure 2, the monthly potential evapotranspirations of Thornthwaite, EVP, and of Penman-Monteith, EV0, are compared for each of the previous sixteen climatologic stations.

Each graph of Figure 2 contains the representation of the results of the linear regression analysis carried out between EVP and EV0 - the straight line segment, its equation and the correlation coefficient - as well as a second dashed straight line segment representing the equality between the two evapotranspirations under consideration.

Figure 2 highlights two relevant issues: i) the values of the potential evapotranspiration of Thornthwaite (EVP) are systematically lower than those of the evapotranspiration of Penman-Monteith (EV0) thus confirming the previous knowledge for Portugal; the differences between those values increase as the evapotranspirations increase; ii) both evapotranspirations under comparison present high correlations, thus suggesting the possibility of, under scarcity of data, estimating EV0 based on EVP.

The former of the previous issues suggests that the application of the sequential water budget technique would yield rather distinct estimations of surface stream flows when based upon one EVP or EV0.

The comparison between monthly stream flows (expressed as water height) obtained through the sequential water budget technique based on the potential evapotranspirations of Thornthwaite (HP) and of Penman-Monteith (H0) is depicted in Figure 3. Such results were obtained assuming a maximum useable water capacity of the soil, Smax, of $150 \mathrm{~mm}$ which allegedly corresponds to the average conditions prevalent in Portugal, though, in fact, the values of Smax are expected to be higher in the South than in the North of the country.

Each graph in Figure 3 represents the straight line segment resulting from the linear regression analysis between HP and $\mathrm{H} 0$, as well as the corresponding equation and correlation coefficient, r. It also includes an auxiliary dashed straight line segment that represents the equality between HP and H0.

In the first place it is important to underline that, for most of the climatologic stations, it is possible to recognize a statistically significant dependency (measured by the high correlation coefficients achieved) between monthly stream flows evaluated on the basis of Thornthwaite (HP) and Penman-Monteith (H0) evapotranspirations.

As the potential evapotranspiration of Thornthwaite (EVP) is always lower than the potential evapotranspiration Penman-Monteith (EV0), its derived monthly stream flows (HP) are higher than those provided by the Penman-Monteith data (H0).

However, significant differences between potential evapotranspirations may not necessarily lead to significant differences between stream flows evaluated based upon such evapotranspirations. Clearly under these circumstances are the results for the climatologic stations of Bragança, Mirandela, Vila Real, Régua, Viseu, Coimbra-Bencanta, Alcobaça, Ota and Sassoeiros, where the monthly stream flows obtained by the water budget technique considering either EVP or EV0 are very close. 

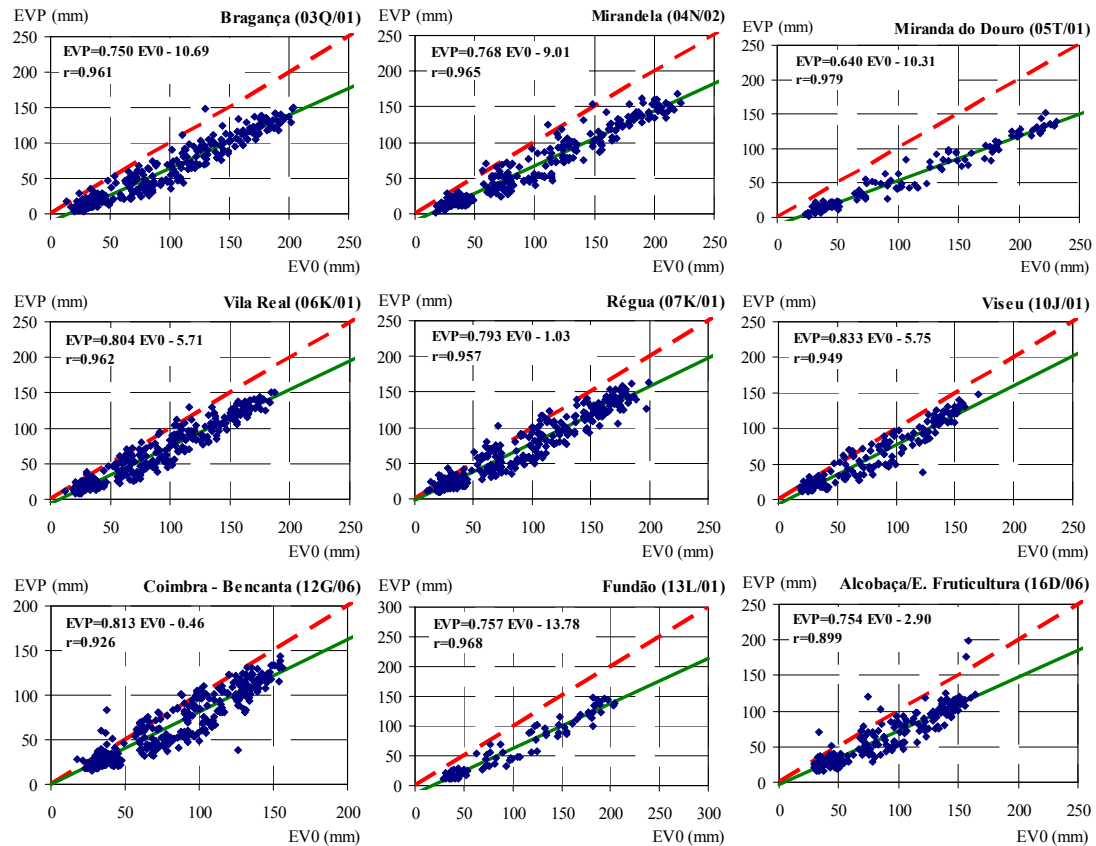

EVP (mm) Alcobaça/E. Fruticultura (16D/06)
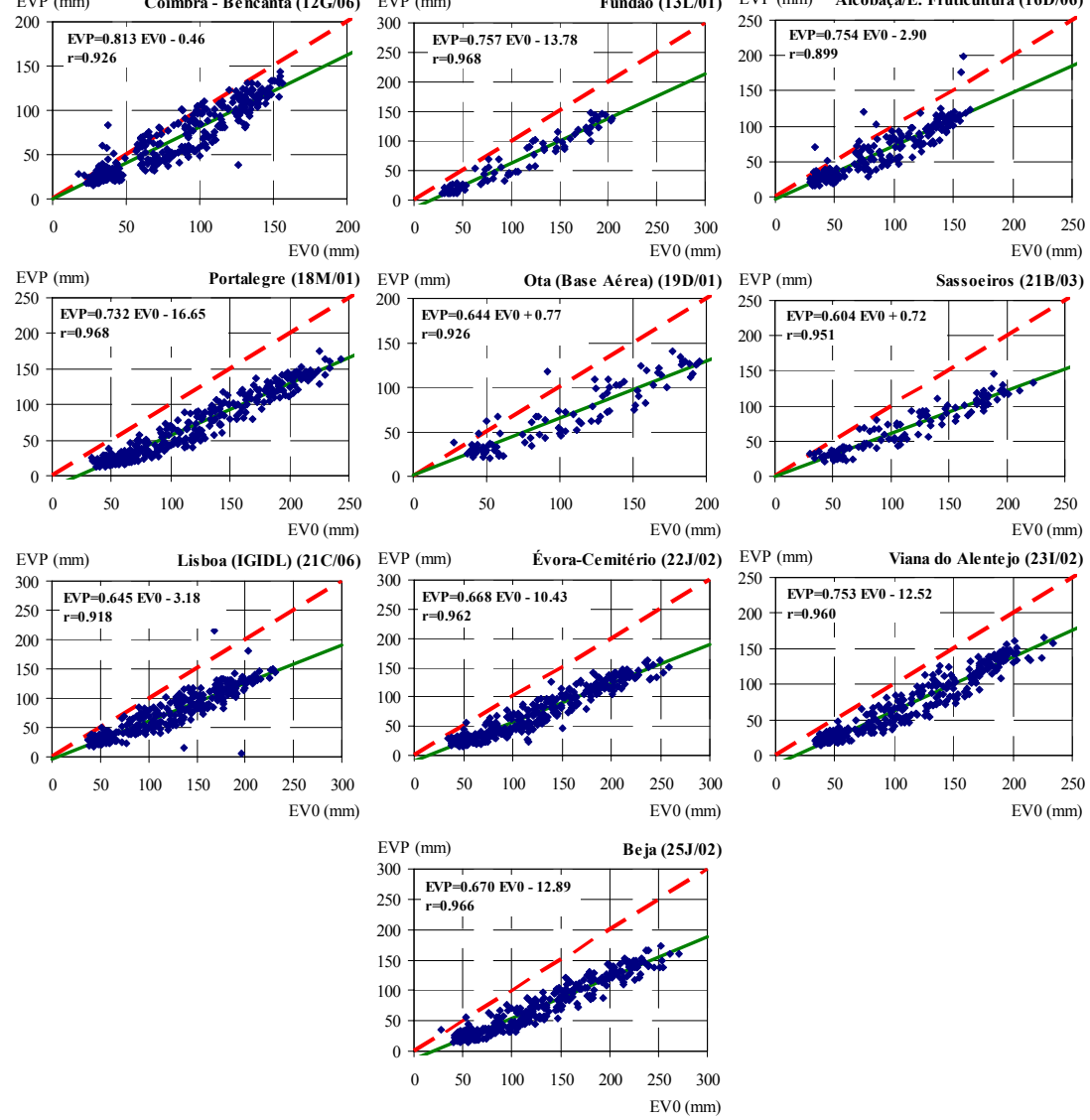

Figure 2: Potential evapotranspirations of Thornthwaite, EVP, and of Penman-Monteith, EV0. Linear regression equations and correlation coefficients, $r$. 

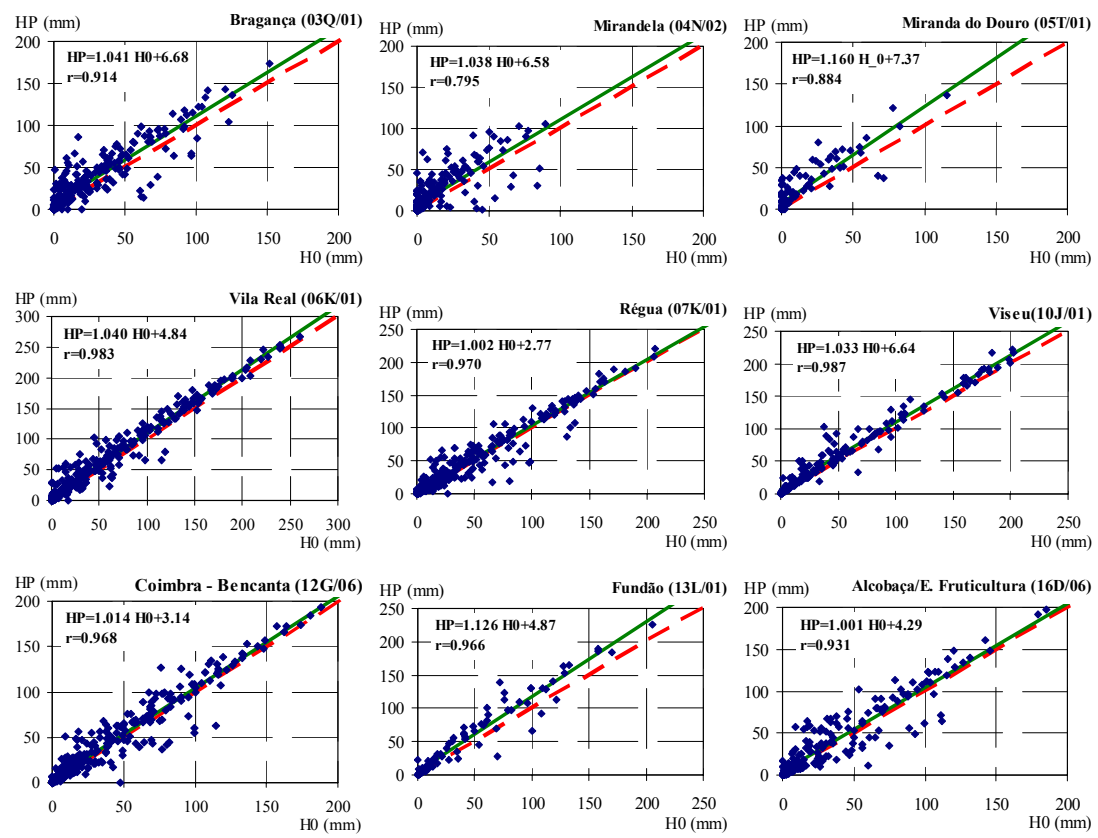

HP (mm) Alcobaça/E. Fruticultura (16D/06)
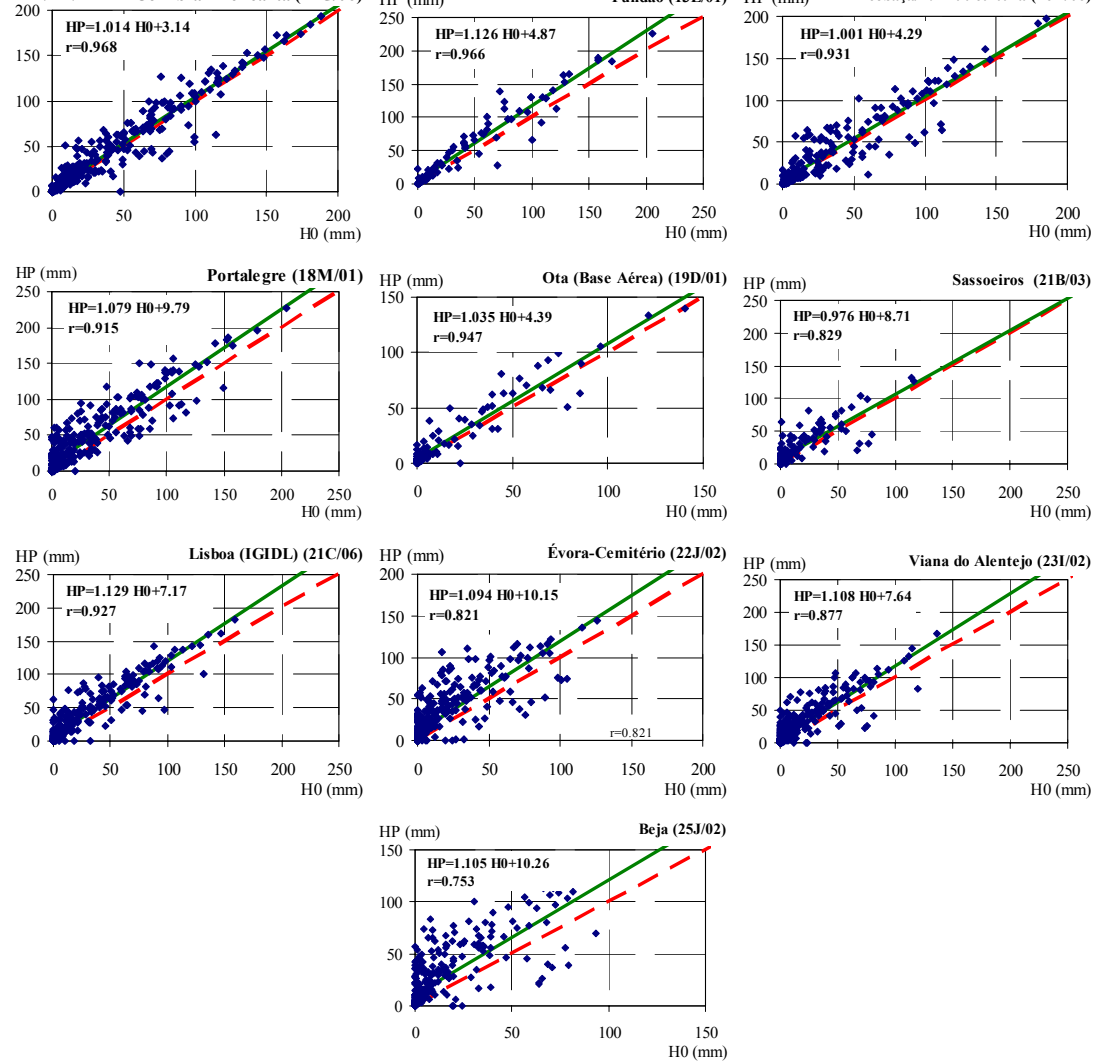

Figure 3: Monthly flows predicted by the sequential water budget technique applied to the evapotranspirations of Thornthwaite (HP) and of Penman-Monteith (H0). Linear regression equations and correlation coefficients, $r$. 
We believe that this highly interesting observation can be explained by the fact that the largest differences between monthly values of EVP and EV0 occur in the dry semester during which the water excess or superavit and, consequently, the surface runoff are no longer controlled by the evapotranspiration being instead a consequence of the low or even non-existing rainfall and ground water content. This situation results in an actual evapotranspiration that is rather unrelated to the potential one since it is limited not by the "potentiality" of the soil and plants to transfer water to the atmosphere, but, instead, by the scarcity of water that inhibits that "potentiality". Under these circumstances the actual evapotranspirations derived either considering EVP or EV0 become very close even when these potential evapotranspirations are quite different.

To emphasise the previous results and conclusions, an example based on the climatologic stations of Vila Real, Viseu and Alcobaça-E. Fruticultura is presented in Figure 4. For each of these stations and for each month, the figure displays the means and the standard deviations of the series of both potential evapotranspirations (EVP and EV0) and of the stream flows predicted by applying the sequential water budget technique to those evapotranspirations (HP and $\mathrm{H} 0$ ).

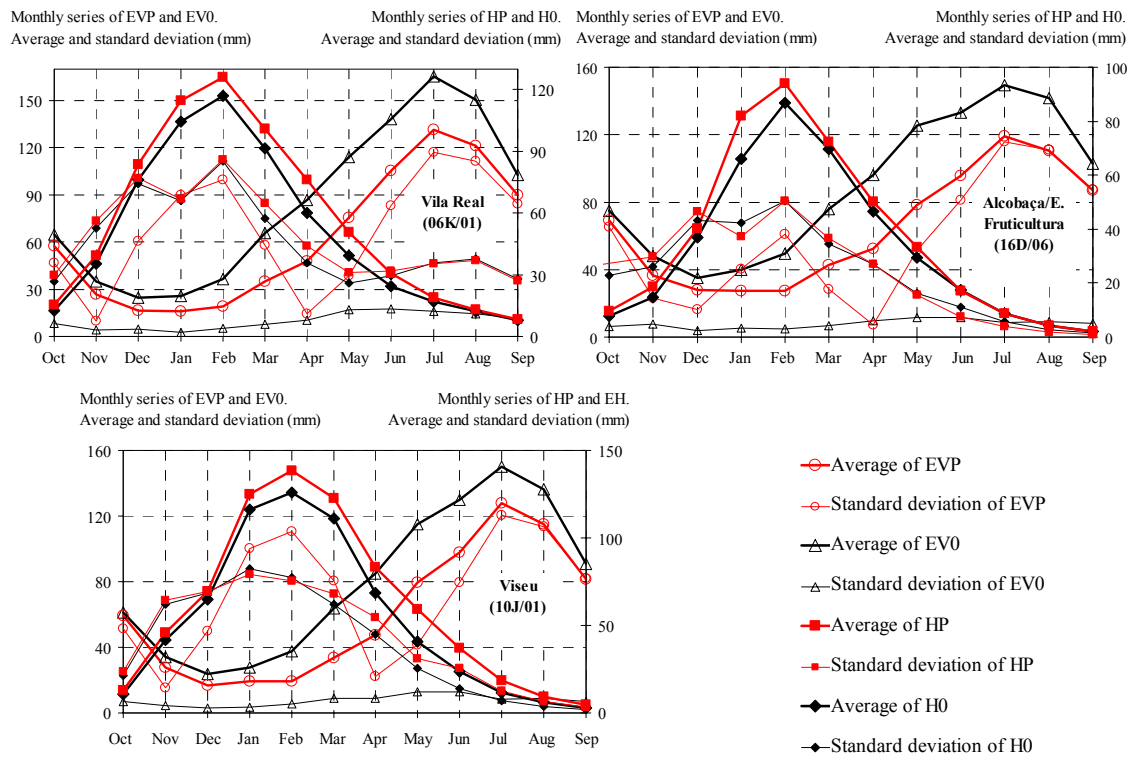

Figure 4: Averages and standard deviation of the monthly series of EVP, EV0, HP and H0 in some of the climatologic stations of Table 1. 
It is observed that, in average, the monthly values of EVP are always lower than those of EV0, the differences being larger in the summer period. However, even in this period, the differences between the monthly mean stream flows HP and $\mathrm{H} 0$ are very small.

It is also important to underline that the month by month variability of the EVP series is larger than the one of the EV0 series (larger standard deviations). Despite this fact, the variability of the flow series obtained from both evapotranspirations is very similar, meaning that the sequential water budget applied to ETP or ET0 yields to monthly stream flows that are very similar, either in value or in what concerns their statistical characteristics.

\section{Discussion and conclusions}

The main conclusions of this study are drawn as follows:

i. The method of Thornthwaite yields to potential evapotranspirations clearly smaller than those resulting from the Penman-Monteith method thus confirming that the former method underestimates the potential evapotranspiration in Portugal. Nevertheless, both monthly potential evapotranspirations of Thornthwaite and Penman-Monteith present a high degree of correlation.

ii. For the majority of the climatologic stations, the sequential water budget technique resulted in monthly stream flows based on the evapotranspiration of Thornthwaite slightly higher than those resulting from the Penman-Monteith evapotranspiration. However, the correlations coefficients between stream flows obtained via one or the other potential evapotranspiration are most of the time relatively high.

iii. The differences in the monthly stream flows obtained by the sequential water budget technique considering one or the other potential evapotranspiration are much smaller than the differences between those evapotranspirations and may even become negligible, particularly in the wet areas of Portugal.

So, in what concerns the main objective of the study briefly presented establishment of a methodology based on hydrological information easily available and having in view the filling of the gaps of the monthly flow series and the increase of the spans of such series - it may be concluded that the potential evapotranspiration of Thornthwaite (despite its poor data requirements) combined with the sequential water budget technique provides a feasible approach.

By means of regression analysis techniques it is also possible to derive the monthly Penman-Monteith potential evapotranspiration from the Thornthwaite one and then to apply the sequential water budget or another estimation model of stream flows, like the Temez model. By this way, the overestimation of monthly stream flows which results from the direct use of EVP, particularly in the dryer regions of the country, is expected to be corrected.

Further developments of the research will necessarily include the comparison between observed flows and predicted flows based on different models applied either to EVP or to EV0. 


\section{References}

[1] Carter, D. B., The average water balance of the Delaware basin. Drexel Institute of Technology, Laboratory Climatology, Publications in Climatology XI (3):249-269, 1958.

[2] Lencastre, A., and Franco, F. M., Lições de hidrologia. Universidade Nova de Lisboa, Portugal, 1984.

[3] Mather, J. R., The climate water budget in environmental analysis. D. $H$. Health Co., Lexington Books, Lexington, MA:39-65,1978.

[4] Mather, J. R., 1981. "Using computed stream flow in watershed analysis". Water Resources Bulletin 17(3):474-482, 1981.

[5] Pereira, L. S.; Allen, R. G.; Raaes, D.; Smith, M., Fao Irrigation and Drainage Paper $n^{\circ} 56$ "Crop Evapotranspiration". Food and Agriculture Organization of the United Nations, Rome, 1998.

[6] Portela, M. M.; Santos, J.; Coelho, F. Alterações em séries de variáveis hidrológicas: seus efeitos nos volumes de água a fornecer para rega e na fiabilidade do fornecimento desses volumes a partir de albufeiras, $8^{\circ}$ Congresso da Água. APRH, Figueira da Foz, Portugal, 2006.

[7] Quintela, A. C., Hidrologia de águas superficiais in Curso Internacional de Hidrologia Operativa, Manual, Vol. II, Direcção-Geral dos Recursos e Aproveitamento Hidráulicos, Lisboa, Portugal, 505-794, 1984.

[8] Thornthwaite, C.W., 1948. An Approach Toward a Rational Classification of Climate, Geographical Review, 38, 55-94, 1948.

[9] Varennes and Mendonça, P., Excerto das Lições de Hidráulica Geral e Agrícola. Instituto Superior de Agronomia $4^{a}$ edição ciclostilada, Lisboa, Portugal, 1972-73. 